\title{
Sanksi Hukum terhadap Pegawai Negeri Sipil yang Melakukan Bolos Kerja
}

\author{
Kiki Rizki Febrian, Suwari Akhmaddhian \\ Fakultas Hukum, Universitas Kuningan, Indonesia \\ Email : kikirizki@gmail.com
}

\begin{abstract}
The purpose of this study is to find out how to regulate sanctions for civil servants who do not enter the office. The research method used is normative juridical, which is an approach method by studying the law which is conceptualized as a norm or rule that applies in society, and serves as a reference for everyone's behavior. data collection tool through library research. ata used secondary, that is data obtained through the study of documentation by reading scientific books, magazines, internet, newspapers and other readings related to research. The results of the study are Civil Servants are elements of the state apparatus, public servants, and public servants who must be a good role model for the community in the behavior, actions and adherence to applicable laws and regulations. To maintain dignity and honor, Civil Servants must carry out the code of ethics and code of conduct as regulated in Law Number 5 of 2014 concerning State Civil Apparatus5 and Government Regulation Number 42 of 2004 concerning Corps of Soul Development and Civil Servant Code of Ethics. Civil Servants have the function and task of implementing public policies in accordance with statutory provisions, professional and quality public services, and national glue and unity.
\end{abstract}

Keywords: sanctions; absent from work; discipline; government employees.

\begin{abstract}
Abstrak
Tujuan penelitian ini adalah untuk mengetahui bagaimana pengaturan terhadap sanksi bagi pegawai negeri sipil yang tidak masuk kantor. Metode penelitian yang digunakan adalah yuridis normatif, yaitu metode pendekatan dengan mengkaji hukum yang dikonsepkan sebagai norma atau kaidah yang berlaku dalam masyarakat, dan menjadi acuan perilaku setiap orang. alat pengumpul data melalui studi kepustakaan. ata yang digunakan sekunder, yaitu data yang diperoleh melalui studi dokumentasi dengan cara membaca buku-buku ilmiah, majalah, internet, surat kabar dan bacaanbacaan lain yang berhubungan dengan penelitian. Hasil penelitian yaitu Pegawai Negeri Sipil adalah unsur aparatur negara, abdi negara, dan abdi masyarakat yang harus menjadi teladan yang baik bagi masyarakat dalam tingkah laku, tindakan dan ketaatan kepada peraturan perundang-undangan yang berlaku. Untuk menjaga martabat dan kehormatan, Pegawai Negeri Sipil harus menjalankan kode etik dan kode perilaku sebagaimana diatur dalam Undang-Undang Nomor 5 Tahun 2014 tentang Aparatur Sipil Negara5 dan Peraturan Pemerintah Nomor 42 Tahun 2004 tentang Pembinaan Jiwa Korps dan Kode Etik Pegawai Negeri Sipil. Pegawai Negeri Sipil mempunyai fungsi dan tugas sebagai pelaksana kebijakan publik sesuai ketentuan peraturan perundangundangan, pelayanan publik yang profesional dan berkualitas, dan perekat dan pemersatu bangsa.
\end{abstract}

Kata Kunci : sanksi; tidak masuk kerja; displin; pegawai negeri sipil.

\section{PENDAHULUAN}

Pegawai Negeri Sipil adalah unsur aparatur negara, abdi negara, dan abdi masyarakat yang harus menjadi teladan yang baik bagi masyarakat dalam tingkah laku, tindakan dan ketaatan kepada peraturan perundang-undangan yang berlaku. Untuk menjaga martabat dan kehormatan, Pegawai Negeri Sipil harus menjalankan kode etik dan kode perilaku sebagaimana diatur dalam Undang-Undang Nomor 5 Tahun 2014 tentang Aparatur Sipil Negara5 dan Peraturan Pemerintah Nomor 42 Tahun 2004 tentang Pembinaan Jiwa Korps dan Kode Etik Pegawai Negeri Sipil. 
Pegawai Negeri Sipil mempunyai fungsi dan tugas sebagai pelaksana kebijakan publik sesuai ketentuan peraturan perundangundangan, pelayanan publik yang profesional dan berkualitas, dan perekat dan pemersatu bangsa. Adapun salah satu kewajiban bagi Pegawai Negeri Sipil antara lain adalah kewajiban untuk menaati segala ketentuan peraturan perundang-undangan. Ketentuan mengenai pedoman sikap, tingkah laku, dan perbuatan Pegawai Negeri Sipil di dalam melaksanakan tugasnya dan pergaulan hidup sehari-hari, sebagaimana diatur dalam Peraturan Pemerintah Nomor 42 Tahun 2004 tentang Pembinaan Jiwa Korps dan Kode Etik Pegawai Negeri Sipil. Selain itu, ketentuan mengenai kewajiban dan larangan bagi Pegawai Negeri Sipil sebagaimana diatur dalam Peraturan Pemerintah Nomor 53 Tahun 2010 tentang Disiplin Pegawai Negeri Sipil. Termasuk ketentuan terkait hal yang privat yaitu menyelenggarakan kehidupan berkeluarga tentang perkawinan dan perceraian.

Disiplin Pegawai Negeri Sipil adalah kesanggupan Pegawai Negeri Sipil untuk menaati kewajiban dan menghindari larangan yang ditentukan dalam peraturan perundangundangan dan/atau peraturan kedinasan yang apabila tidak ditaati atau dilanggar dijatuhi hukuman disiplin. Pelanggaran disiplin adalah setiap ucapan, tulisan, atau perbuatan PNS yang tidak menaati kewajiban dan/atau melanggar larangan ketentuan disiplin PNS, baik yang dilakukan di dalam maupun di luar jam kerja.

Kelancaran pelaksanaan Pemerintahan dan Pembangunan Nasional terutama tergantung dari kesempurnaan Aparatur Negara dan kesempurnaan Aparatur Negara pada Pokoknya tergantung dari kesempurnaan Pegawai Negeri.2 Pegawai Negeri sempurna menurut Marsono adalah Pegawai Negeri yang penuh kesetiaan kepada Pancasila, UndangUndang Dasar 1945 dan Pemerintah yang bersatu padu, bermental baik, berdisiplin tinggi, berwibawa, berdaya guna, berkualitas tinggi dan sadar akan tanggung jawab sebagai unsur pertama Aparatur Negara. ${ }^{1}$ Maka dari itu rumusan masalah yang di dapat dari paparan latar belakang di atas adalah Sanksi hukum terhadap Pegawai Negeri Sipil yang bolos kerja?.

\section{METODE PENELITIAN}

Metode penelitian yang digunakan oleh penulis adalah Yuridis Normatif, dengan alat pengumpul data melalui studi kepustakaan yaitu studi dokumentasi peraturan perundangundangan serta artikel-artikel yang terkait dengan penelitian ini.

\section{HASIL DAN PEMBAHASAN}

\section{A. Pengertian Etika}

Etika adalah kumpulan azas atau nilai yang berkenaan dengan akhlak mengenai benar dan salah yang dianut satu golongan atau masyarakat. Perilaku dapat diartikan sebagai tanggapan atas reaksi individu yang terwujud dalam gerakan (sikap) dan ucapan yang sesuai dengan apa yang dianggap pantas oleh kaidah-kaidah hukum yang berlaku. Etika berperilaku adalah sikap dan perilaku yangg didasarkan kepada kematangan jiwa yang diselaraskan dengan norma-norma yang berlaku di dalam masyarakat.

\footnotetext{
${ }^{1}$ I Made Surya Permana Putra, I Wayan Parsa, Ni Gusti Ayu Dyah Satyawati, Penjatuhan Sanksi Terhadap Pelanggaran Disiplin Pegawai Negeri Sipil, Jurnal, Hlm 2.
} 
sikap dan perilaku individu dan kelompok aparatur negara yang didasari atas nilai-nilai yang diyakini kebenarannya dan telah menjadi sifat serta kebiasaan dalam melaksanakan tugas dan pekerjaan sehari-hari. ${ }^{2}$

Menurut Kamus Besar Bahasa Indonesia (Departemen P dan K, 1988), etika dijelaskan dengan membedakan tiga arti sebagai berikut.(1).Ilmu tentang apa yang baik dan apa yang buruk dan tentang hak dan kewajiban moral (akhlak); (2).Kumpulan asas atau nilai yang berkenaan dengan akhlak. (3).Nilai mengenai benar dan salah yang dianut suatu golongan/ masyarakat. Nilai-nilai etika harus diletakkan sebagai landasan atau dasar pertimbangan dalam setiap tingkah laku manusia termasuk kegiatan di bidang keilmuan. 2 "Nilai" dimaksudkan kondisi atau kualitas suatu benda atau suatu kegiatan yang membuat eksistensinya, pemilikannya, atau upaya mengejarnya menjadi sesuatu yang diinginkan oleh individuindividu masyarakat. Nilai tidak selalu bersifat subjektif, karena ia tetap mengacu pada konteks sosial yang membentuk individu dan yang pada gilirannya dipengaruhi olehnya. Aspek nilai inilah yang menjadikan etika sebagai suatu teori mengenai hubungan antar pribadi dan membedakannya dari nilai-nilai intelektual atau estetis semata-mata. Nilai etis secara logis dapat diwujudkan dalam hubungannya antara manusia dengan sesama manusia.

\section{B. Pengertian Kode Etik}

Kode etik merupakan aturan tertulis yang secara sistematik sengaja dibuat berdasarkan prinsip-prinsip moral yang ada dan pada saat yang dibutuhkan dapat difungsikan sebagai alat untuk menghakimi segala macam tindakan yang secara logika rasional umum common sense dinilai menyimpang dari kode etik. Kode etik adalah sebuah pernyataan yang terwujud sebagai aturan-aturan moral yang biasanya tertulis yang dibuat oleh sebuah organisasi. Kode etik PNS berisi ajaran-ajaran moral, asasasas etis atau asas-asas kelakuan yang baik yang dapat dijadikan sebagai pedoman bertindak di dalam melaksanakan pelayanan publik. ${ }^{3}$

\section{Pengertian Profesi}

Perkataan profesi dan profesional sudah sering digunakan dan mempunyai beberapa arti. Dalam percakapan sehari-hari, perkataan profesi diartikan sebagai pekerjaan (tetap) untuk memperoleh nafkah (Belanda: baan; Inggris: job atau occupation), yang legal maupun yang tidak. Jadi, profesi diartikan sebagai setiap pekerjaan untuk memperoleh uang. Dalam arti yang lebih teknis, profesi diartikan sebagai setiap kegiatan tetap tertentu untuk memperoleh nafkah yang dilaksanakan secara berkeakhlian yang berkaitan dengan cara berkarya dan hasil karya yang bermutu tinggi dengan menerima bayaran yang tinggi. Keakhlian tersebut diperoleh melalui proses pengalaman, belajar pada lembaga pendidikan (tinggi) tertentu, latihan secara intensif, atau kombinasi dari semuanya itu. Dalam kaitan pengertian ini, sering dibedakan pengertian profesional dan profesionalisme sebagai lawan

2 Prof Dr Zudan Arif Fakrulloh, SH,MH, Kode Etik Penyelenggara Negara Dalam Mewujudkan Good Governance, Jurnal, hlm 13 .

3 Thea Santiarsti. Salmin Dengo, Joorie M. Ruru, Penerapan Etika PNS Dalam Pelaksanaan Tugas Aparatur Pelayanan Publik, Jurnal, Hlm 3. 
dari amatir dan amatirisme, misalnya dalam dunia olah-raga, yang sering juga dikaitkan pada pengertian pekerjaan tetap sebagai lawan dari pekerjaan sambilan.

\section{Larangan bagi Pegawai Negeri Sipil}

Dalam pasal 4 Bab II bagian kedua Peraturan Pemerintah Nomor 53 Tahun 2010 tentang Disiplin Pegawai Negeri Sipil, memuat larangan-larangan sebagai berikut;

1. menyalahgunakan wewenang;

2. menjadi perantara untuk mendapatkan keuntungan pribadi dan/atau orang lain dengan menggunakan kewenangan orang lain;

3. tanpa izin Pemerintah menjadi pegawai atau bekerja untuk negara lain dan/atau lembaga atau organisasi internasional;

4. bekerja pada perusahaan asing, konsultan asing, atau lembaga swadaya masyarakat asing;

5. memiliki, menjual, membeli, menggadaikan, menyewakan, atau meminjamkan barangbarang baik bergerak atau tidak bergerak,dokumen atau surat berharga milik negara secara tidak sah;

6. melakukan kegiatan bersama dengan atasan, teman sejawat, bawahan, atau,orang lain di dalam maupun di luar lingkungan kerjanya dengan tujuan untuk keuntungan pribadi, golongan, atau pihak lain, yang secara langsung atau tidak langsung merugikan negara;

7. memberi atau menyanggupi akan memberi sesuatu kepada siapapun baik secara langsung atau tidak langsung dan dengan dalih apapun untuk diangkat dalam jabatan;

8. menerima hadiah atau suatu pemberian apa saja dari siapapun juga yang berhubungan dengan jabatan dan/atau pekerjaannya;

9. bertindak sewenang-wenang terhadap bawahannya;

10. melakukan suatu tindakan atau tidak melakukan suatu tindakan yang dapat menghalangi atau mempersulit salah satu pihak yang dilayani sehingga mengakibatkan kerugian bagi yang dilayani;

11. menghalangi berjalannya tugas kedinasan;

12. memberikan dukungan kepada calon Presiden/Wakil Presiden, Dewan Perwakilan Rakyat, Dewan Perwakilan Daerah, atau Dewan Perwakilan Rakyat Daerah dengan cara:

a. ikut serta sebagai pelaksana kampanye;

b. menjadi peserta kampanye dengan menggunakan atribut partai atau atribut PNS;

c. sebagai peserta kampanye dengan mengerahkan PNS lain; dan/atau

d. sebagai peserta kampanye dengan menggunakan fasilitas negara;

13. memberikan dukungan kepada calon Presiden/Wakil Presiden dengan cara:

a. membuat keputusan dan/atau tindakan yang menguntungkan atau merugikan salah satu pasangan calon selama masa kampanye; dan/atau

b. mengadakan kegiatan yang mengarah kepada keberpihakan terhadap pasangan calon yang menjadi peserta pemilu sebelum, selama, dan sesudah masa kampanye meliputi pertemuan, ajakan, himbauan, seruan, atau pemberian barang kepada PNS dalam lingkungan unit kerjanya, anggota keluarga, dan masyarakat; 
Logika : Journal of Multidisciplinary Studies, ISSN 2085-9970.

Vol. 10 Nomor 01 Juni 2019. 31-39.

14. memberikan dukungan kepada calon anggota Dewan Perwakilan Daerah atau calon Kepala Daerah/Wakil Kepala Daerah dengan cara memberikan surat dukungan disertai foto kopi Kartu Tanda Penduduk atau Surat Keterangan Tanda Penduduk sesuai peraturan perundangundangan;

15. memberikan dukungan kepada calon Kepala Daerah/Wakil Kepala Daerah, dengan cara:

a. terlibat dalam kegiatan kampanye untuk mendukung calon Kepala Daerah/Wakil Kepala Daerah;

b. menggunakan fasilitas yang terkait dengan jabatan dalam kegiatan kampanye;

c. membuat keputusan dan/atau tindakan yang menguntungkan atau merugikan salah satu pasangan calon selama masa kampanye; dan/atau

d. mengadakan kegiatan yang mengarah kepada keberpihakan terhadap pasangan calon yang menjadi peserta pemilu sebelum, selama, dan sesudah masa kampanye meliputi pertemuan, ajakan, himbauan, seruan, atau pemberian barang kepada PNS dalam lingkungan unit kerjanya, anggota keluarga, dan masyarakat.

\section{E. Hukuman Disiplin}

Pasal 5, PNS yang tidak menaati ketentuan sebagaimana dimaksud dalam pasal 3 dan/atau pasal 4 dijatuhi hukuman disiplin, Pasal 6, Dengan tidak mengesampingkan ketentuan dalam peraturan perundang-undangan pidana, PNS yang melakukan pelanggaran disiplin dijatuhi hukuman disiplin. Disiplin kerja seringkali dilihat dimana seorang pegawai bisa datang ke kantor dan pulang dari kantor tepat waktu. Selain itu, disiplin kerja pegawai juga dapat dilihat dari setiap kepatuhan pegawai untuk taat dan tunduk pada peraturan yang berlaku. Kedisiplinan merupakan fungsi operatif dari Manajemen Sumber Daya Manusia. Kedisiplinan merupakan fungsi operatif MSDM yang terpenting karena semakin baik disiplin pegawai, semakin tinggi prestasi kerja yang dapat dicapainya. Tanpa disiplin pegawai yang baik, sulit bagi organisasi pemerintahan mencapai hasil yang optimal. ${ }^{4}$

\section{F. Sanksi hukum bagi PNS yang bolos kerja}

Penetapan sanksi terhadap pelanggaran disiplin PNS merupakan konsekuensi terhadap bentuk pelanggaran yang dilakukan oleh Pegawai Negeri Sipil dalam melaksanakan tugasnya. Jadi, bentuk evaluasi kinerja merupakan upaya yang dilakukan pemerintah dalam melaksanakan fungsi pengawasan terhadap perilaku PNS yang tujuannya adalah untuk menjaga kredibitas, harkat dan martabat PNS di mata masyarakat. ${ }^{5}$

Penegakan hukum berupa sanksi juga diterapkan agar menimbulkan efek jera baik bagi pelaku pelanggaran disiplin maupun Pegawai Negeri Sipil lain agar tidak melakukan kesalahan yang sama. Keputusan penjatuhan hukuman disiplin tingkat berat terhadap yang bersangkutan telah dilakukan secara profesional. Ini merupakan hasil kerja tim terpadu

\footnotetext{
4 Muhammad Ari Noviyanto, Hesti Lestari, Efektifitas Surat Keputusan Gubernur Jawa Tengah Nomor 8oo/o9623 Tentang Kedisiplinan Terhadap Kinerja Pegawai Negeri Sipil Di Sekretariat Daerah Provinsi Jawa Tengah, Jurnal, Hlm 4-5.

5 Tedi Sudrajat, Problematika Penegakan Hukuman Dispilin Kepegawaian, Jurnal, Vol.8, Hlm 215.
} 
yang bekerja secara independen, melalui prosedur sebagaimana yang telah diatur dalam Peraturan Pemerintah Nomor 53 Tahun 2010 tentang Disiplin Pegawai Negeri Sipil. ${ }^{6}$

Upaya kedisiplinan Pegawai Negeri di Indonesia yang berkaitan dengan pemberian sanksi, bahwa sanksi administrasi ditujukan kepada perbuatan yang melanggar ketentuan dalam pegawai negeri sipil yang dimaksudkan agar perbuatan pelanggaran itu dihentikan. ${ }^{7}$ Sanksi hukum bagi PNS yang tidak masuk kerja terdapat pada pasal 8 ayat 9 Peraturan Pemerintah Nomor 53 Tahun 2010 Tentang Disiplin Pegawai Negeri Sipil. Pasal 8 ayat 9 yaitu masuk kerja dan menaati ketentuan jam kerja sebagaimana dimaksud dalam Pasal 3 angka 11 berupa:

a. teguran lisan bagi PNS yang tidak masuk kerja tanpa alasan yang sah selama 5 (lima) hari kerja;

b. teguran tertulis bagi PNS yang tidak masuk kerja tanpa alasan yang sah selama 6 (enam) sampai dengan 10 (sepuluh) hari kerja; dan

c. pernyataan tidak puas secara tertulis bagi PNS yang tidak masuk kerja tanpa alasan yang sah selama 11 (sebelas) sampai dengan 15 (lima belas) hari kerja;

Banyak PNS yang baru diberikan sanksi setelah tidak masuk kerja melebihi 46 hari. Padahal, dalam aturannya seorang pegawai yang tidak masuk kerja tanpa alasan yang jelas harus segera dijatuhi hukuman disiplin sesuai dengan tingkat pelanggaran yang ada (sejumlah hari yang telah ditinggalkan) tanpa harus menunggu sampai batas lebih dari 46 hari. $^{8}$

\section{G. Faktor lain yang mempengaruhi kinerja}

Faktor lain yang mempengaruhi kinerja dan kepuasan kerja pegawai dalam melaksanakan tugas adalah lingkungan kerja yaitu segala sesuatu yang ada di sekitar pekerja, yang dapat mempengaruhi dirinya dalam menjalankan tugas. Faktor lingkungan kerja bisa berupa kondisi fisik kantor yang meliputi penerangan, suhu udara, dll yang mampu meningkatkan suasana kondusif dan semangat kerja serta berpengaruh terhadap kinerja pegawai. Faktor lain yang mempengaruhi kinerja dan kepuasan kerja pegawai dalam melaksanakan tugas adalah lingkungan kerja yaitu segala sesuatu yang ada di sekitar pekerja, yang dapat mempengaruhi dirinya dalam menjalankan tugas. ${ }^{9}$ Terbatasnya alokasi sumber dana pembinaan aparatur terutama untuk meningkatkan skill aparatur melalui berbagai pendidikan dan pelatihan dalam rangka menunjang pelayanan publik, beragamnya responsibilitas sumber daya aparatur untuk meningkatkan keterampilan dan keahlian sehingga upaya peningkatan keterampilan dan keahlian aparatur kurang optimal, beragamnya kesadaran kolektif aparatur untuk mengikuti pendidikan dan pelatihan, baik yang difasilitasi Kantor maupun atas partisipasi sendiri, kurang efektifnya disiplin kerja

\footnotetext{
${ }^{6}$ Ayunda Puspita, Penjatuhan Sanksi Pemberhentian Dengan Hormat Tidak Atas Permintaan Sendiri Sebagai Pegawai Negeri Sipil Terhadap Pelanggaran Disiplin Berat, Jurnal, Hlm 5.

7 Kusno,SH.,MH, Penerapan Peraturan Pemerintah Nomor 53 Tahun 2010 Tentang Disiplin Pegawai NegeriI Sipil Di Indonesia, Jurnal, Hlm 31.

8 Wildan Lutfi A, Mayahayati K, Implementasi Peraturan Pemerintah Nomor 53 Tahun 2010 Tentang Disiplin Pegawai Khususnya Aspek Jam Kerja Di IKabupaten Kutai Kartanegar, Jurnal, Vol.11, Hlm 342.

9 Anak Agung Ngurah Bagus Dhermawan, I Gde Adnyana Sudibya, I Wayan Mudiartha Utama, Pengaruh Motivasil, Lingkungan kerja, Kompetensi, Dan Kompensasi Terhadap Kepuasan Kerja Dan Kinerja Pegawai Di Lingkungan Kantor Dinas Pekerjaan Umum Provinsi Bali, Jurnal, Vol.6, Hlm 174.
} 
Logika : Journal of Multidisciplinary Studies, ISSN 2085-9970.

Vol. 10 Nomor 01 Juni 2019. 31-39.

pegawai dan kurang memegang teguh etika profesional pegawai sehingga membawa konsekuensi terhadap kualitas pelayanan. ${ }^{10}$

\section{H. Kasus pelanggaran kode etik terhadap Pegawai Negeri Sipil yang tidak masuk kerja}

Badan Pertimbangan Kepegawaian (Bapek) dalam sidang di Kantor Kementerian Pendayagunaan Aparatur Negara dan Reformasi Birokrasi (PANRB) memberhentikan 16 pegawai negeri sipil ( $\underline{\text { PNS }}$ ) dari instansi pemerintah pusat dan daerah. Sidang tersebut digelar pada 30 Juli 2018. Selain itu, ada tiga PNS yang dikenai sanksi turun pangkat selama tiga tahun. Menteri PANRB, Asman Abnur, selalu Ketua Bapek mengungkapkan, ada 11 orang dari 8 instansi pemerintah pusat dan 8 orang dari 7 pemerintah daerah yang diberhentikan dengan hormat atas permintaan sendiri. Adapun tiga PNS diberikan sanksi turun pangkat selama tiga tahun, baik dari instansi pusat maupun pemerintah daerah.

Sebagian besar kasus PNS yang diberhentikan karena tidak masuk kerja lebih dari 46 hari. Ini menjadi peringatan bagi seluruh ASN," ujar Asman, seperti dikutip dari

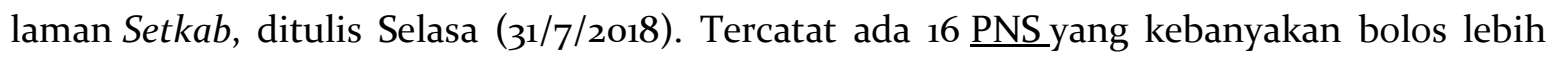
dari 46 hari, dua orang menjadi calo CPNS, penyalahgunaan narkotika, melakukan pungli, pemalsuan dokumen CPNS. Sebelumnya, Badan Kepegawaian Nasional (BKN) telah memblokir data kepegawaian terhadap 188 aparatur sipil negara (ASN) atau disebut PNS yang telah ditetapkan dalam keputusan hukuman tetap (inkracht) dan belum diberhentikan oleh Pejabat Pembina Kepegawaian (PPK) instansinya.

Namun tak berhenti sampai di situ, langkah tersebut masih terus berlanjut dan tercatat sampai dengan kondisi per 20 Juli 2018, terhitung 231 ASN Korupsi yang telah diblokir. Dihimpun dari database kepegawaian nasional yang dikelola BKN, daftar 231 nama ASN yang diblokir tersebut diketahui merupakan pegawai yang tersebar di 56 instansi pemerintah, dengan rincian 1 orang ASN bekerja pada 1 instansi pemerintah pusat dan 230 orang ASN bekerja pada 55 pemerintah daerah. "Di 55 pemerintah daerah (pemda), 230 ASN yang datanya telah terblokir tersebut terdiri dari 55 ASN bekerja pada instansi pemerintah provinsi, 40 ASN bekerja pada instansi pemerintah kota, dan 135 ASN bekerja pada instansi pemerintah kabupaten," ujar Kepala Biro Humas BKN Mohammad Ridwan di Jakarta, Jumat 27 Juli 2018.

Langkah pemberhentian kepada PNS korupsi yang telah inkracht harus segera dilakukan sesuai dengan peraturan perundangan-undangan mengingat tindakan korupsi menyangkut kerugian negara dan wibawa birokrasi. "ASN yang dijatuhi hukuman penjara karena melakukan tindak pidana korupsi harus diberhentikan tidak dengan hormat terhitung mulai akhir bulan sejak putusan pengadilan atas perkaranya yang telah inkracht," kata dia. Jika tindakan pemberhentian tidak dilakukan, kata Ridwan, hasil pengawasan bersama akan ditindaklanjuti oleh BKN dan KPK sesuai kewenangan dan regulasi yang berlaku. Hal tersebut sudah dituangkan lewat kerja sama BKN-KPK dan Surat Kepala BKN Nomor K26-30/V 55-5/99 tanggal 17 April 2018 perihal Koordinasi Bersama Terkait Pengawasan dan Pengendalian Kepegawaian kepada seluruh PPK Instansi.

${ }^{10}$ Yuslim, Djumadi, Sugandi, Pembinaan Sumber Daya Aparatur Dalam Meningkatkan Pelayanan Publik di Kantor Camat Tenggarong Kabupaten Kutai Kartanegara, Jurnal, Hlm 578. 


\section{SIMPULAN}

Pegawai Negeri Sipil adalah unsur aparatur negara, abdi negara, dan abdi masyarakat yang harus menjadi teladan yang baik bagi masyarakat dalam tingkah laku, tindakan dan ketaatan kepada peraturan perundang-undangan yang berlaku. Untuk menjaga martabat dan kehormatan, Pegawai Negeri Sipil harus menjalankan kode etik dan kode perilaku sebagaimana diatur dalam Undang-Undang Nomor 5 Tahun 2014 tentang Aparatur Sipil Negara5 dan Peraturan Pemerintah Nomor 42 Tahun 2004 tentang Pembinaan Jiwa Korps dan Kode Etik Pegawai Negeri Sipil. Pegawai Negeri Sipil mempunyai fungsi dan tugas sebagai pelaksana kebijakan publik sesuai ketentuan peraturan perundangundangan, pelayanan publik yang profesional dan berkualitas, dan perekat dan pemersatu bangsa.

\section{SARAN}

Pegawai Negeri Sipil atau di singkat PNS ini adalah sebagai aparatur negara yang seharusnya bisa menjadi contoh yang baik atau tolak ukur masyarakat dalam berperilaku, agar tidak terjadi adanya suatu pelanggaran yang dilakukan oleh PNS, harus memperhatikan kompetensi pegawai agar tidak terjadi suatu pelanggaran kode etik.

\section{DAFTAR PUSTAKA}

Anak Agung Ngurah Bagus Dhermawan, I Gde Adnyana Sudibya, I Wayan Mudiartha Utama, Pengaruh Motivasi, Lingkungan Kerja, Kompetensi, Dan Kompensasi Terhadap Kepuasan Kerja Dan Kinerja Pegawai Di Lingkungan Kerja Dinas Pekerjaan Umum Provinsi Bali, Jurnal,Agustus 2012,Vol.6.

Ayunda Puspita, Penjatuhan Sanksi Pemberhentian Dengan Hormat Tidak Atas Permintaan Sendiri Sebagai Pegawai Negeri Sipil Terhadap Pelanggaran Disiplin Berat, Jurnal.

I Made Surya Permana Putra, I Wayan Parsa, Ni Gusti Ayu Dyah Satyawati, Pemjatuhan Sanksi Terhadap Pelanggaran Disiplin Pegawai Negeri Sipil, Jurnal.

Kusno, Penerapan Peraturan Pemerintah Nomor 53 Tahun 2010 Tentang Disiplin Pegawai Negeri Sipil Di Indonesia, Jurnal Ilmiah “Advokasi”, Maret 2014, Vol. 02.

Muhammad Ari Noviyanto, Hesti Lestari, Efektifitas Surat Keputusan Gubernur Jawa Tengah Nomor 80o/og623 Tentang Kedisiplinan Terhadap Kinerja Pegawai Negeri Sipil Di Sekretariat Daerah Provinsi Jawa Tengah, Jurnal.

Tedi Sudrajat, Problematika Penegakan Hukuman Disiplin Kepegawaian, Jurnal Dinamika Hukum, September 2008, Vol.8.

Thea Santiarsti, Salmin Dengo, Joorie M. Ruru, Penerapan Etika PNS Dalam Pelaksanaan Tugas Aparatur Pelayanan Publik, Jurnal.

Wildan Lutfi A, Mayahayati K, Implementasi Peraturan Pemerintah Nomor 53 Tahun 2010 Tentang Disiplin Pegawai Khususnya Aspek Jam Kerja Di Kabupaten Kutai Kartanegara, Jurnal Borneo Administrator, Tahun 2015, Vol.11. 
Logika : Journal of Multidisciplinary Studies, ISSN 2085-9970.

Vol. 10 Nomor 01 Juni 2019. 31-39.

Yuslim, Djumadi, Sugandi, Pembinaan Sumber Daya Aparatur Dalam Meningkatkan Pelayanan Publik di Kantor Camat Tenggarong Kabupaten Kutai Kartanegara, Jurnal Administrative Reform, Tahun 2013, Vol.1.

Zudan Arif Fakrulloh, Kode Etik Penyelenggara Negara Dalam Mewujudkan Good Governance, Jurnal.

Peraturan Pemerintah Nomor 42 Tahun 2004 Tentang Pembinaan Jiwa Korps dan Kode Etik Pegawai Negeri Sipil.

Peraturan Pemerintah Nomor 53 Tahun 2010 Tentang Disiplin Pegawai Negeri Sipil. 